\title{
The Black Tree’s Memory (Černá pamět stromu)
}

\author{
Author: Lumír Čivrný
}

First Published: 1974 (in samizdat), 1991 (official publication)

\begin{abstract}
About the Author: Lumír Čivrný (1915-2001) was a Czech journalist, writer and translator. He was born in Červený Kostelec in East Bohemia as the son of a dyer in a textile factory. He studied law, French, German, comparative and aesthetic studies at Charles University in Prague. From 1936 to 1938 he was a member of the Communist-oriented literary group Blok (The Bloc). During World War II he was active in the resistance, he was imprisoned by the Gestapo. After the war, he occupied various political functions in the parliament and the Communist government, among others as a Deputy Minister of Education or Deputy Minister of Culture. Since 1954 he became a freelance writer and translator from Spanish, German, French, Portuguese and Bulgarian (Federico García Lorca, Nicolás Guillén, Rutebeuf, Charles Cros, Rainer Maria Rilke etc.). During the Prague Spring, he was engaged in political reforms; this is the reason he could not publish in the 1970s and 1980s.
\end{abstract}

Further Important Publications: Co se vejde do života (2000, What a Life Contains; memoirs); Bylo takové ticho (2005, ed. Václav Daněk, It Was So Silent; anthology of poems).

\section{Content and Interpretation}

The novel describes the story of the Czech Jewish doctor Rudy Fleischner trying to save himself from persecution during the Holocaust. The book is set in the time period from 1942 to 1945 . The author states in the dedication of the book that it was inspired by the real life of his friend, doctor Jindřich Urban.

The book consists of six chapters; the first five are followed by so-called "pauses" (,odmlky“). The texts of these chapters describe the adventurous journey of Rudy using the internal perspective and internal monologue of the protagonist, while the pauses are reflections full of existential thoughts of the sense of being human using the external perspective of the author.

The last chapter differs because it takes place after the war has already ended when Rudy returns home - to Prague. Here he finds just one of his beloved women, Mařka, and he learns that the other one, Staša, has died in a concentration camp. In the previous five chapters, the author describes retrospectively Rudy's escape from the camp in Izbica on the border of Poland and Ukraine where he had worked as a doctor. He had met another important woman in his life - Mrs Salzerová there whose high moral character causes him to be ashamed and who accompanies him for the rest of the time in his thoughts.

Rudy already escapes from Izbica in the first chapter. One Polish widow gives him clothes and documents belonging to her husband killed by the Germans as well as

Ә Open Access. ( 2021 Marie Brunová, published by De Gruyter. (cc) BY-NC-ND This work is licensed under a Creative Commons Attribution-NonCommercial-NoDerivatives 4.0 License. https://doi.org/10.1515/9783110671056-010 
some money, and Rudy pretends to be a Pole. From Izbica he gets to Skole - a small town near Lviv. Here Rudy hides in the mountains during the winter along with two Jewish families - the rich one is named Lejbs and the poor one Tambors. After their shelter is betrayed and all the Lejbs are shot down, Rudy escapes with the Tambors. However, Rudy becomes seriously ill and the Tambors must leave him in a village with a hunter. After a short recovery, Rudy manages to join the group of Jews working on the railway construction. He is lucky because he is able to treat the illness of Rockteschl, a sick German foreman who then protects him and provides him with benefits like sleeping in a separate room or getting a package with clothes from Mařka's sister. Unfortunately, after a conflict between Rockteschl and Bauführer (building site manager) Müller, Rudy must leave Skole. His friends provide him with food and help him to get into the train. The next stop on Rudy's journey is the small town of Bárcs in Hungary on the border with Croatia. Using a false identity again, this time as the Polish doctor Stefan Nowak, Rudy works as a doctor for some time before he is denounced (probably by his colleague doctor Jesenski) and arrested. The last thing the reader learns about Rudy's life are his stay in prison and finally his transport from Hungary. Rudy's future life is explained in the last chapter. After being transported from Bárcs, he is taken away to the concentration camp Oberlanzendorf where he is later liberated by the Americans. Then he works as an interpreter for American Captain Shirra and comes back to Prague with the Captain, where he meets Mařka and her friend Klára who have both survived concentration camps.

\section{Main Topics and Problems}

The book was written in the 1960s. It was ready to print in 1970 but after the beginning of "normalisation", the typeset was destroyed. This is why the novel was published in samizdat and the official edition could not be published until the Velvet Revolution.

The first main topic of the novel is the memory which becomes the moral criterion showing the protagonists the right way. The memory means the permanent presence in the protagonist's consciousness and thoughts of the people he has met. The old prisoner Witting says in the last chapter the memory is saved in the black naked branches of the tree standing above the apelplac, the black tree's memory (Čivrný, 1991, p. 218). Actually it is "the memory that is protecting the protagonist even in the moments of his despair and that [...] defeats the despair in the limit situation" (Balajka, 1991, p. 15). The memories of the people Rudy has met during his life run like a scarlet thread through the whole novel. Rudy speaks often to these people in his thoughts and asks for their opinion. Particularly his girlfriend Staša and his co-prisoner from Izbica Mrs Salzerová both become a kind of imaginary arbiter of Rudy's life and doing. In this sense, The Black Tree's Memory is related to many other literary works; the memory, as the communicative memory as well as the cultural memory (Assmann, 1995), is the dominant theme of Holocaust literature.

Another important topic of this book is fear. This topic also appears very often in novels and short stories that thematise the Shoah, for instance Hana Bělohradská's 
$\rightarrow$ Without Beauty, without a Collar, Ladislav Grosman's $\rightarrow$ The Shop on Main Street or Michał Głowiński's $\rightarrow$ The Black Seasons. The last sentence of Čivrný's book says that "fear became his only mission" (Čivrný, 1991, p. 242). Rudy feels the fear almost all the time on his hard journey. He hopes to lose his fear after the end of the war. Nevertheless, he can still feel it even in Prague. He recognises that the fear will always accompany him. But, "Rudy's mission - the fear - is a value protecting all of humanity, not only his individual life” (Kadlečík, 1991, pp. 243-244). Jews are depicted differently in the novel. On the one hand, some Jews help the protagonist, on the other hand, Orthodox Jews in Hungary distance themselves from him and Rudy takes a dislike to them.

However, it may seem that the novel is a distressful odyssey of Rudy's almost miraculous rescue. Actually, it is a "deeply reflexive deliberation about the place of a human being who is trapped and who has lost all human dimensions and has been reduced to a number which can be erased at any moment. It is a novel about how not to yield to evil even if there are no means how to resist it” (Balajka, 1991, p. 15).

\section{Cited Works}

Balajka, B. (1991). Pamět proti strachu. Tvar, 2(48), p. 15. Čivrný, L. (1991). Černá pamět' stromu. Praha: Československý spisovatel. Kadlečík, I. (1991). Moudrá pamět' stromu In: L. Čivrný, Černá pamět stromu. Praha: Československý spisovatel, pp. 243-246.

\section{Further References}

Assmann, J. (1995). Erinnern, um dazuzugehören. Kulturelles Gedächtnis, Zugehörigkeitsstruktur und normative Vergangenheit. Erinnerung und kollektive Identitäten. In: K. Platt, D. Mihran, eds., Generation und Gedächtnis. Opladen: Leske\&Budrich, pp. 51-75. Cinger, F. (2015). Je proč se vracet. Právo, 25(265), 13.11., p. 18. Palán, A. (2015). Příběhy z minulosti. Hospodářské noviny, 59 (191), 2.10., attachment Ego!. Šnellerová, T. (2016). Lumír Čivrný: Černá pamět’ stromu. A2, 12(7), p. 31. 